\title{
Covid-19 Moderates the Relationship between Financial Inclusion Disclosure and Banking Industry Performance: Theoretical Framework
}

\section{Mai Mohammed Alm El-Din Accounting Lecturer at CIC- Cairo \\ Mai_a_eldin@cic-cairo.com}

\begin{abstract}
Ahmed Mohammed Ameen Accounting Lecturer at AAST Ameen248@hotmail.com
\end{abstract}

\begin{abstract}
The Leaders in developing countries continue to make vigorous efforts to ensure sustainable financial progress to promote economic-level improvements in the livelihoods of their citizens. These efforts have led to some financial developments over the past few years, which include participation in the activities of financial inclusion. Financial inclusion has become one of the pillars of economic growth because of its ability to integrate the informal economy of individuals and institutions into the formal economic structure. Also, financial inclusion disclosure falls under the umbrella of corporate social responsibility disclosure, which affects the financial performance of banks.

On the other hand, the escalation of the COVID-19 pandemic at the end of 2019 is a global example of the fragility of the world we live in and the extent to which we as a society are exposed to exceptional risks, the ongoing COVID-19 pandemic; it threatens to wipe out years of progress that financial inclusion strategies have made. Because of the constant needs of stakeholders, especially during the period of a pandemic, it was necessary to disclose more additional information related to financial inclusion activities during the COVID-19 pandemic, therefore, the effect on firm performance. Despite the importance of financial inclusion on the international level. However, there is a relative dearth of literature addressing the impact of Covid-19 on the relationship between financial inclusion and the level of non-financial disclosure, especially those in Egypt.
\end{abstract}

Keywords: Banks performance; Covid-19; Developing Countries; Egypt; Financial Inclusion Disclosure; Information Overloading. 


\section{Introduction}

Financial inclusion is a concept that has spread strongly over the past few years, especially in developing countries. Financial inclusion depends on access to financial services for all citizens and the ability to benefit from those services by encouraging them to manage their money and savings.

Financial inclusion is one of the tools that the state uses to achieve a sustainable development strategy (Egypt, 2030), which seeks to provide all financial services to various groups, especially the poor. In addition to, focusing on providing financing for small and medium enterprises to reduce the size of the informal economy in the country, as the financial transactions of these groups are carried out in cash and far from banking. The increasing awareness of the financial inclusion activities has led to increased stakeholder's needs from the firms to provide additional information about their future strategies to engage in financial inclusion activities. The financial inclusion activities fall under the definition of Corporate Social Responsibility (CSR)-related activities (Eccles and Serafeim, 2013).

On the other hand, the emerging Covid-19 appeared in the last quarter of 2019. The global Corona pandemic has led to social distancing, social spacing, and dueling, and has blinded many governments after taking the precautionary measures, people stayed at home, and social isolation in the conflict extended for several months. Social distancing with the development of the new Coronavirus, and this virus has led to an increase in the use of social media platforms, media, by (61\%), spending more time on social media, for socializing with friends and colleagues, and relatives, after teleworking the various electronic means of communication (He et al., 2020). Larcker et al. (2020) argue that the first company that discloses the impact of covid-19 was Starbucks on January 28. The coffee giant, which derives 14 percent of its sales from China, referenced the potential impact of the virus on its Chinese operations in a subsequent-event notification. Bose et al. (2016) argue that the disclosure of the financial inclusion activities can 
reduce the information asymmetry between managers and stakeholders, besides, reduce agency costs, and improves banks' profitability. In the context of the agency costs, the agency theory supports that the voluntary disclosure of the additional information may reduce the agency costs (Lozano et al. 2015; Sassen and Azizi, 2018). The disclosure of financial inclusion activities is considered within the disclosure of non-financial information related to social responsibility activities within banks (Bose et al. 2016). The non-financial information is considered to complement the financial information in evaluating the overall performance, in addition to helping to create a competitive advantage and improving profitability.

Accordingly, this study aims to answer the following questions: Q1: Does the financial inclusion disclosure affect banks' performance for Egyptian-listed banks? Q2: Does the relationship between financial inclusion disclosure and performance change after inserting the effect of Covid-19 as a moderator variable for this relationship?

The main objective of this study is to show the theoretical framework for the relationship between financial inclusion disclosure and bank performance of listed banks in the Egyptian context and expect the impact of Covid-19 on this relationship. First, the study focuses on financial inclusion because it could lead to increasing the level of disclosure, and it is one of the activities of social corporate responsibility. Second, Covid-19 is one of the reasons behind expanding the disclosure (Larcker et al., 2020). Finally, this study develops the theoretical framework about the relationship between financial inclusion disclosure and the impact of Covid-19 on this relationship.

The study contributes to the best of our knowledge, very few researchers showed the effect of Covied-19 on the relationship between financial inclusion and bank performance in emerging capital markets. The remainder of this study is organized as follows. The first section presents the literature review that dealt the financial inclusion in developing and developed countries. Also, describes the financial inclusion conceptual 
framework in detail and the determinants of financial inclusion disclosure. The third section shows the relationship between financial inclusion disclosure and performance during Covid-19. Finally, conclude the study and Suggestions for Future Research.

\section{Literature Review}

\subsection{Financial Inclusion Conceptual Framework}

Financial inclusion is one of the important topics that emerged on the international level, after the outbreak of the financial crisis. It became clear that the global interest of financial institutions, central banks, and monetary institutions in the issue of financial inclusion is no less important than the interest in strengthening the capabilities of the small and medium enterprises sector. Financial inclusion can be understood in light of the definition of a United Nations report, as providing financial services to the poor classes permanently and at affordable costs, to integrate this segment of society into the formal economy (United Nations, 2016). It also refers to the individual's possession of an account in a formal financial institution, which allows him to have many financial services including saving, borrowing officially, obtaining insurance contracts, or using payment services, thus the financial inclusion leads to a higher level of economic benefits (Zins, and Weill, 2016). Financial inclusion provides individuals with low incomes with the possibility to save for the future, which enhances stability in personal finance, and allows high levels of bank deposits that contribute to securing a more stable deposit base for banks during difficult times (Han and Melecky, 2013).

Financial inclusion is the primary objective of many developing countries in the past decade (Ismail et al., 2018). There have been many objectives related to the need for financial Inclusion. Andrianaivo and Kpodar (2011) show that there are many benefits of financial inclusion. Statistics show that more than a billion people do not have a bank account. Statistics also indicate that $48 \%$ of adults are in developing countries. They 
have bank accounts, and that $46 \%$ of men have a bank account compared to $30 \%$ of women. These countries. Access to finance has many benefits, the most important of which are:

1- Savings protection: as most of the savings of the poor are simple amounts that fall under the bank's laws.

2- Payment of wages.

3- Better management of their farms and small enterprises.

4- Social Development: Social development is defined as promoting a sustainable society fitting human dignity by empowering marginalized groups of men and women to fulfill their mission of community development, improve its social and economic position, and gain its rightful place in society.

5- Human development: where the human development index is measured from three dimensions, namely: longevity, Knowledge and adult literacy, decent standard of living through an adequate income level. These are the indicators of financial inclusion.

Despite emphasized that the importance of expanding the application of financial inclusion is not only an objective development but also it is an issue that should be on the top priorities of banks because this policy would work to stabilize the bank and the banking sector in general (Ahamed and Mallick, 2019). In this context, Inoue (2019) indicated the challenges of financial inclusion that include poverty, regulations inadequate legislation, rampant corruption and favoritism, literacy, and fighting unemployment. Moreover, the difficulties in the use of technology, the futility or complexity of banking products, usury in the system The current economic economy, famine, and the challenges are many, but they are not a major obstacle if the strength is there The efforts of government agencies, financial institutions, and the charitable sector have been united. Besides, we can achieve a lot for these poor people. 


\subsection{The determinants of the financial inclusion}

There is prior literature that examined the determinants of financial inclusion. Andrianaivo and Kpodar (2011) investigated whether financial inclusion is one of the channels through which information and communication technologies influence economic growth, using a sample of African countries from 1988 to 2007. Their results confirm that information and communication technologies including mobile phone development account for economic growth in African countries. Part of this effect comes from financial inclusion, and, at the same time, the development of mobile phones consolidates the impact of financial inclusion on economic growth, especially in countries where mobile financial services take hold. Besides, Zins and Weill, (2016) showed the determinants of financial inclusion in Africa, by using a sample of 37 African countries on the World Bank's Global index. They find that financial inclusion with a higher influence on education and income. Therefore, mobile banking and traditional banking are driven by the same determinants. They also indicated that there is a difference between the determinants of informal finance and those of formal finance. Furthermore, Evans (2016) documented the determinants of financial inclusion for the period 2005-2014 in Africa, using the panel data approach. This study finds that broad money (the percentage of GDP), per capita income, literacy, and Islamic banking presence are significant factors showing the level of financial inclusion. Also, the domestic credit provided by the financial sector (percentage of GDP), inflation, and population have insignificant effects on financial inclusion.

In the same context, Nandru et al., (2016) examined the impact of the use of banking services and ownership of bank account as determinants of financial inclusion. Using structured questionnaire in Union Territory of Pondicherry region in India. The results indicate that education and income level as determinants of financial inclusion have a significant impact on financial inclusion. One of the most important studies in this context was 
conducted by Aleen et al., (2016) that examined the relationship between financial inclusion indicators and individual characteristics. Moreover, the relationship between financial inclusion and country characteristics, using a sample of 123 countries. Their results indicated that higher financial inclusion is associated with a better enabling environment to access financial services, such as greater proximity to branches, fewer documentation requirements to open an account, and lower banking costs. Policies targeted to promote inclusion such as government requirements to offer basic or lowfee accounts, exempting small or rural depositors from onerous documentation requirements, and the use of bank accounts for government payment is especially effective among rural residents and the poor.

\section{Financial inclusion disclosure, Firm Performance, and}

\section{Covid-19 pandemic}

In this section, we present an overview of the recent literature on financial inclusion. We present the main results that can answer the questions of the current study. Fareed et al. (2017) examined the relationship between financial inclusion and women entrepreneurship in Mexico across informal and formal work and economic sectors. They used a panel dataset over the period 2009-2015. The results show that there is a positive relationship between financial inclusion and entrepreneurship However, the positive relationship between financial inclusion and women entrepreneurship does not hold for women entrepreneurs working in the informal sector or women working in the commerce sector. The results also show the existence of gender disparity in the status of entrepreneurship across formal and informal work in Mexico. On average, women are about 56\% less likely to be entrepreneurs in the formal sector and $63 \%$ more likely to be entrepreneurs in the informal sector, as compared to men, after taking into account other relevant individual and municipality level characteristics that are important in explaining entrepreneurship. Besides, Agyemang et al. (2018) investigated the impact of financial inclusion on the determinants of the 
specific macroeconomic with fixed effect panel data. The results find that there is a negative relationship between financial inclusion and both poverty and income inequality in Africa. Besides. They recommended, that policies that will enhance the financial inclusion of the poor and marginalized in the financial sector should be pursued in the selected African countries.

Regarding the context of financial inclusion disclosure and firm performance, Bose et al. (2017) examined the relationship between financial inclusion disclosure and firm performance and examined the roles of market competition and government ownership as moderator variables on this relationship. Using a final sample of 161 banking firm-year observations during the period 2009-2014 in Bangladeshi. Through a financial inclusion disclosure index, which consisting of 13 components of determining the financial inclusion disclosure based on the Central Bank of Bangladesh Guidance. The results show there is a positive relationship between the financial inclusion disclosure and banking firms' future performance; also, the results find the empirical evidence that banks participation in financial inclusion activities will increase their market share, also, the disclosure of the financial inclusion information will reducing the information asymmetry. Also, Chauvet and Jacolin (2017) examined the effect of financial inclusion on firm performance in emerging countries. Using a sample of 55,596 firms in 79 countries, the results find that financial inclusion has a positive effect on firm performance. Besides, hattacharyya et al. (2019) examined the association of Corporate Social Responsibility expenditure and financial inclusion with the banking performance in the period after the introduction of the legislation, using both stock market and accounting measures of performance, during the period 2015-2017 for Indian banks. The results show that the level of CSR expenditure and degree of financial inclusion is not associated with banks' financial performance when performance is measured in accounting terms. However, a significant negative association is found when performance is measured by stock market return. Furthermore, de Villiers and van Staden (2011) find that there is a negative relationship 
between environmental disclosure and economic performance, using a return on assets as a proxy of the economic performance.

Regarding the effect of Covid-19 on the accounting practices, GarcíaSánchez and García-Sánchez (2020) analyzed the involvement that large Spanish companies have shown during the toughest moments of the pandemic. In addition to determining the main objectives of these companies during Covid-19. Using a final sample of 100 companies that reported their Corporate Social Responsibility activities on their websites. The findings show that several companies have shown a great commitment to society, developing actions that alleviate the consequences of the COVID-19. Loughran and McDonald (2020) examined the relationship between disclosure the risk factors and the stock price. They found that there is a negative relationship between disclosing the risk factors and the stock price, they would expect more than $21 \%$ of the sample companies disclosing their company's risk exposures to consider a pandemic as a substantive business disruption. Besides, Im et al. (2021) examined how hospitality companies deploy such narrative strategies with impression management during the COVID-19 pandemic. They content-analyzed 57 CEO letters, which were published by hospitality companies during the COVID-19. They found the prevalent rhetoric appeals and patterns of rhetoric appeals with impression management tactics embedded in the letters. Qiu et al. (2021) revealed that engaging in Corporate Social Responsibility activities could increase the stakeholder attention and stock returns of hospitality firms during Covid-19. Community-related Corporate Social Responsibility activities have a stronger effect on the stock returns. The results also show that hospitality firms that pursue improved stock market performance during Covid-19 can invest in Corporate Social Responsibility activities to protect customers, employees, and communities from attracting further stakeholder attention.

According to agency theory and legitimacy theory as one of the theories supporting and explaining the use of disclosure practices. Companies may resort to increasing these practices to reduce the problem of 
agency. In addition to compliance with the laws of society and similar institutions. Due to the prevalence and modernity of Covid-19, in addition, the need for users of financial reporting for additional information that may help them to understand the financial situation of institutions and companies (Shehata, 2014; Lozano et al., 2015; De villiers and Marques, 2016; Hummel and Schlick, 2016; Daddi et al., 2018). Moreover, according to the results of previous studies, which have supported the existence of a positive relationship between disclosure of financial inclusion activities as being within the activities of corporate social responsibility and the financial performance of institutions, the increase in disclosure practices resulting from the spread of the Covid-19. Therefore, the current study expects that there is an effect of the spread of Covid-19 on the strength and direction of the relationship between financial inclusion disclosure and the financial performance of institutions. As increasing disclosure, practices are sometimes considered an information overload ${ }^{1}$, in this context, many studies have indicated that there is a positive relationship between increasing disclosure practices and information overload. The Information Overload Theory as one of the theories supporting and explaining the phenomenon of information overload argues that individuals have a limited ability to integrate and evaluate information when making decisions, as this ability is related to the amount of information available to individuals when making decisions. The more information, the more decreased ability of individuals to integrate and process available information, thus influencing the decisionmaking process (Ji et al., 2014).

To sum, there are some gaps found in the financial inclusion literature. First, several studies have examined the relationship between financial inclusion activities and other variables such as future performance; however,

\footnotetext{
${ }^{1}$ Information overload results by providing users with a large amount of unnecessary information with reduced ability to process that information (Fang et al., 2018; Chung et al., 2019), which leads to misleading investors and directing their reactions and decisions to what the company deems appropriate. (Cardinaels et al., 2017; Wang et al., 2018).
} 
these studies have mixed results. Second, no study addresses the relationship between financial inclusion disclosure and banking industry performance in Egypt up to date, although financial inclusion disclosure is one of the determinants of banks performance, to the best of our knowledge. Finally, there is a deficiency of studies, which show the moderating role of Covid-19 on the relationship between financial inclusion disclosure and bank performance.

\section{Conclusion}

The covid-19 pandemic affected the financial performance of companies, as a result of the negative economic effects of this crisis on all sectors, Its financial effects have been reflected in the financial reports prepared after the events of the Covid-19, a significant impact is expected from this crisis. There are also potential effects of Covid-19 on the results of companies 'business and their financial statements on 31/12/2020. Financial reports starting from the financial reports prepared in the first quarter of 2020. In this paper, we have shown the relationship between financial inclusion disclosure and banking industry performance, and the effect of Covid-19 on this relationship. While the existing literature only showed the relationship between financial inclusion disclosure and firm performance, the novelty of this paper is explained the moderator's role of Covid-19 on this relationship. Our findings clearly show that there is a positive relationship between the level of financial inclusion disclosure financial and performance. This result is depended on the findings of the literature review. Abd El Hafiez (2018) argues that the financial inclusion activities In Egypt banks' are not mandatory under the existing laws. Banks can voluntarily engage in such activities and disclose this information, whereas CBE encourages banks to engage in financial inclusion activities, by reducing their reserve ratios for them from $14 \%$ to $12 \%$ (CBE website 1 ). Therefore, the authors can conclude that $\mathrm{CBE}$ directives and regulations can be one of the determinants of the financial inclusion disclosure 
Our findings provide theoretical support for the beneficial role of financial inclusion activities and add to the growing body of financial inclusion literature that explores the benefits of banking engagement in financial inclusion activities.

\section{Suggestions for Future Research}

Further research could examine the impact of the financial inclusion activities disclosure level on the banks' profitability and propose an index for measuring the level of financial inclusion disclosure by the commercial banks in Egypt. Future research is needed to examine the impact of Covid19 on a banking firm's financial performance. 


\section{References}

Agyemang-Badu, A.A., Agyei, K. and Kwaku Duah, E. (2018), "Financial inclusion, poverty, and income inequality: Evidence from Africa", Agyemang-Badu, AA, Agyei. K. and Duah, EK Financial Inclusion, Poverty and Income Inequality: Evidence from Africa, Spiritan International Journal of Poverty Studies, Vol. 2 No. 2.

Ahamed, M.M. and Mallick, S.K. (2019), "Is financial inclusion good for bank stability? International evidence", Journal of Economic Behavior \& Organization, Vol. 157, pp.403-427.

Allen, F., Demirguc-Kunt, A., Klapper, L. and Peria, M.S.M. (2016), "The foundations of financial inclusion: Understanding ownership and use of formal accounts", Journal of Financial Intermediation, Vol. 27, pp.1-30.

Andrianaivo, M. and Kpodar, K. (2011), "ICT, financial inclusion, and growth: Evidence from African countries".

Bhattacharyya, A., Wright, S. and Rahman, M.L. (2019), "Is better banking performance associated with financial inclusion and mandated CSR expenditure in a developing country?", Accounting \& Finance.

Bose, S., Bhattacharyya, A. and Islam, S. (2016), "Dynamics of firm-level financial inclusion: Empirical evidence from an emerging economy". Journal of Banking and Finance Law and Practice, Vol. 27 No. 1, pp.47-68.

Bose, S., Saha, A., Khan, H.Z. and Islam, S. (2017), "Non-financial disclosure and market-based firm performance: The initiation of financial inclusion", Journal of Contemporary Accounting \& Economics, Vol. 13 No. 3, pp.263-281.

Cardinaels, E., Hollander, S. and White, B.J. (2017), "Automatic summarization of $\begin{array}{lll}\text { corporate } & \text { disclosures, } & \text { Retrieved }\end{array}$ https://www.nhh.no/globalassets/departments/accounting -auditing-andlaw/seminar-papers/chw-manuscript-July-14-2017.pdf".

Chauvet, L. and Jacolin, L. (2017), "Financial inclusion, bank concentration, and firm performance", World Development, Vol. 97, pp.1-13.

Chung, D.Y., Hrazdil, K., Novak, J. and Suwanyangyuan, N. (2019), "Does a large amount of information in corporate disclosures hinder or enhance price discovery in the capital market?", Journal of Contemporary Accounting \& Economics, Vol. 15 No. 1, pp.36-52. 
Daddi, T., Todaro, N.M., De Giacomo, M.R. and Frey, M. (2018), “A systematic review of the use of organization and management theories in climate change studies”, Business Strategy and the Environment, Vol. 27 No. 4, pp.456-474.

De Villiers, C. and Marques, A. (2016), “Corporate social responsibility, countrylevel predispositions, and the consequences of choosing a level of disclosure", Accounting and Business Research, Vol. 46 No. 2, pp.167-195.

Eccles, R.G. and Serafeim, G. (2013), "Sustainability in financial services is not about being green", HBR Blog Network, Vol. 15.

Evans, O. (2016), "Determinants of financial inclusion in Africa: A dynamic panel data approach".

Fang, L., Pittman, J., Zhang, Y. and Zhao, Y. (2018), "Accounting Standard Precision, Corporate Governance, and Accounting Restatements".

Fareed, F., Gabriel, M., Lenain, P. and Reynaud, J. (2017), "Financial inclusion and women entrepreneurship: Evidence from Mexico".

García-Sánchez, I.M., and García-Sánchez, A. (2020), "Corporate social responsibility during COVID-19 pandemic", Journal of Open Innovation: Technology, Market, and Complexity, Vol. 6 No. 4, p.126.

Han, R. and Melecky, M. (2013), "Financial inclusion for financial stability: Access to bank deposits and the growth of deposits in the global financial crisis". The World Bank.

He, P., Niu, H., Sun, Z. and Li, T. (2020), "Accounting index of COVID-19 impact on Chinese industries: A case study using big data portrait analysis", Emerging Markets Finance and Trade, Vol. 56 No. 10, pp.2332-2349.

Hummel, K. and Schlick, C. (2016), “The relationship between sustainability performance and sustainability disclosure-Reconciling voluntary disclosure theory and legitimacy theory", Journal of Accounting and Public Policy, Vol. 35 No. 5, pp. 455-476.

Im, J., Kim, H. and Miao, L. (2021), "CEO letters: Hospitality corporate narratives during the COVID-19 pandemic", International Journal of Hospitality Management, Vol. 92, p.102701.

Inoue, T. (2019), "Financial inclusion and poverty reduction in India", Journal of Financial Economic Policy. 
Ismail, E.A., Wahab, L.A.E. and Ibrahim, A.S. (2018), "Measuring Financial Inclusion in Egypt".

Ji, Q., Ha, L. and Sypher, U. (2014), "The role of news media use and demographic characteristics in the possibility of information overload prediction", International Journal of Communication, Vol. 8, p.16.

Larcker, D.F., Lynch, B., Tayan, B. and TayLor, D.J. (2020), "The spread of Covid19 disclosure", Rock Center for Corporate Governance at Stanford University Closer Look Series: Topics, Issues, and Controversies in Corporate Governance No. CGRP-84.

Larcker, D.F., Lynch, B., Tayan, B. and TayLor, D.J. (2020), "The spread of Covid19 disclosure. Rock Center for Corporate Governance at Stanford University Closer Look Serie", Topics, Issues, and Controversies in Corporate Governance No. CGRP-84.

Loughran, T. and McDonald, B., 2020. Management disclosure of risk factors and COVID-19. Available at SSRN 3575157.

Lozano, R., Carpenter, A., and Huisingh, D. (2015), “A review of theories of the firm and their contributions to Corporate Sustainability. Journal of Cleaner Production, Vol. 106, pp. 430-442.

Nandru, P., Byram, A. and Rentala, S.A. (2016), "Determinants of financial inclusion: Evidence from account ownership and use of banking services", International Journal of Entrepreneurship and Development Studies, Vol. 4 No 2, pp.141155.

Qiu, S.C., Jiang, J., Liu, X., Chen, M.H. and Yuan, X. (2021), "Can corporate social responsibility protect firm value during the COVID-19 pandemic?", International Journal of Hospitality Management, Vol. 93, p.102759.

Sassen, R. and Azizi, L. (2018), "Voluntary disclosure of sustainability reports by Canadian universities", Journal of Business Economics, pp.1-41.

Shehata, N.F. (2014), “Theories and determinants of voluntary disclosure", Accounting and Finance Research (AFR), Vol. 3 No. 1.

United Nations, (2016), "Digital financial inclusion. International telecommunication union (ITU), issue brief series, an inter-agency task force on financing for development, July. United Nations. Available at: 
http://www.un.org/esa/ffd/wp content/uploads/2016/01/Digital-Financial Inclusion_ITU_IATFIssue- Brief.pdf.

Wang, Z., Hsieh, T.S. and Sarkis, J. (2018), "CSR Performance and the Readability of CSR Reports: Too Good to be True?", Corporate Social Responsibility and Environmental Management, Vol. 25 No. 1, pp.66-79.

Zins, A. and Weill, L. (2016), "The determinants of financial inclusion in Africa", Review of development finance, Vol. 6 No. 1, pp.46-57. 